\title{
EFEK EKSTRAK KULIT MANGGIS TERHADAP GAMBARAN HISTOPATOLOGI HEPAR TIKUS WISTAR YANG DIINDUKSI FORMALIN
}

\author{
Afiana Rohmani ${ }^{1}$, Maya Dian Rakhmawatie \\ 1. Staff pengajar FK UNIMUS \\ Wonodri Sendang 2A Semarang \\ Email : afiana@unimus.ac.id
}

\begin{abstract}
Abstrak
Latar Belakang : Jejas kimia formalin dapat memacu terbentuknya senyawa reactive oxygen species (ROS) yang dapat menyebabkan kerusakan seluler jtubuh. Kulit manggis dikenal sebagai antioksidan alamiah dari kandungan xanton di dalamnya.

Tujuan: mengetahui efek pemberian ekstrak kulit manggis terhadap gambaran histopatologi hepar pada tikus wistar yang diinduksi larutan formalin.

Metode Penelitian : 24 ekor tikus dibagi menjadi 4 kelompok . Kelompok pertama merupakan kelompok kontrol negatif (K-), hanya diberi placebo saja hingga masa terminasi. Kelompok kedua merupakan kelompok kontrol positif (K+) yang diinduksi formalin peroral selama 21 hari, kemudian diberi placebo selama 7 hari. Kelompok ketiga sebagai kelompok Perlakuan 1 (P1) yang diinduksi formalin peroral selama 21 hari kemudian diberi ekstrak kulit manggis 200mg/kg BB/ hari selama 7 hari. Kelompok keempat sebagai kelompok Perlakuan 2 (P2) yang diinduksi formalin peroral selama 21 hari kemudian diberi ekstrak kulit manggis $400 \mathrm{mg} / \mathrm{kg} \mathrm{BB} /$ hari selama 7 hari. Setelah itu tikus diterminasi dan diambil organ heparnya untuk dibuat preparat histopatologi.
\end{abstract}

Hasil : Terdapat perbedaan yang signifikan $(\mathrm{p}=0,008)$ gambaran histopatologi jaringan hepar pada kelompok tikus yang diberi ekstrak kulit manggis 400mg/kg BB/hari (P2) dengan kelompok kontrol positif (K+). Tidak terdapat perbedaan yang signifikan $(\mathrm{p}=0,715)$ gambaran histopatologi jaringan hepar pada kelompok tikus yang diberi ekstrak kulit manggis $200 \mathrm{mg} / \mathrm{kg} \mathrm{BB} / \mathrm{hari}(\mathrm{P} 1)$ dengan kelompok kontrol positif $(\mathrm{K}+)$. Terdapat perbedaan yang signifikan $(0,00)$ gambaran histopatologi jaringan hepar kelompok kontrol negatif (K-) dengan ketiga kelompok yang diinduksi formalin, baik diberi ekstrak kulit manggis (P1 dan P2) maupun yang tidak $(\mathrm{K}+)$

Kata kunci : formalin, kulit manggis, gambaran histopatologi hepar. 


\section{Abstract}

Formalin is a xenobiotic that is now commonly used as a preservative in the food industry. The liver is an organ that has the highest metabolic capacity as compared to other organs. Mangosteen or Garcinia mangostana Linn (GML) peel contains xanthones, which are a source of natural antioxidants. The purpose of this study is to evaluate the effects of mangosteen peel extract on liver histopathology in Wistar rats induced by formalin solution.

Methods: an experimental laboratory study involving 24 rats were divided into 4 groups. The first group is the negative control group (K), only given placebo until the time of termination. The second group is the positive control group $(\mathrm{K}+)$ induced by formalin orally for 21 days, and then were given a placebo for 7 days. The third group as group treatment 1 (P1) ,which formalin induced orally for 21 days and then given a mangosteen peel extract $200 \mathrm{mg} / \mathrm{kg} /$ day for 7 days. The fourth group as treatment group 2 (P2), which formalin induced orally for 21 days and then given a mangosteen peel extract $400 \mathrm{mg} / \mathrm{kg} /$ day for 7 days. Finally rats were terminated. The differences of histopatology appereance of liver tissue were analized.

Results: There were significant differences $(\mathrm{p}=0.008)$ on histopathology of liver tissue in rats fed a mangosteen peel extract $400 \mathrm{mg} / \mathrm{kg} /$ day $(\mathrm{P} 2)$ with the positive control group $(\mathrm{K}+)$. There were no significant difference $(\mathrm{p}=$ 0.715) on histopathology of liver tissue in rats fed a mangosteen peel extract $200 \mathrm{mg} / \mathrm{kg} /$ day (P1) with the positive control group $(\mathrm{K}+)$. There were significant differences $(0.00)$ on histopathology of liver tissue negative control group (K) with three groups of formalin-induced, either given mangosteen peel extract (P1 and P2) or not $(\mathrm{K}+$ ).

Keywords: formaldehyde, mangosteen skin, liver histopathology

\section{LATAR BELAKANG}

Formalin merupakan larutan yang tidak berwarna dan baunya sangat menusuk. Di dalam formalin terkandung sekitar 37 persen formaldehid dalam air, sebagai bahan pengawet biasanya ditambahkan metanol hingga 15 persen. Terdapat 4 rute paparan terhadap formaldehide, yaitu melalui inhalasi, ingesti, kulit dan mata. Paparan formaldehide di dalam tubuh akan dimetabolisme dengan cepat baik secara inhalasi maupun ingesti, namun sedikit lamban bila melalui paparan kulit maupun mata. ${ }^{1,2,3}$

Formaldehide dalam tubuh dapat bereaksi kuat terhadap makromolekul, termasuk DNA dan protein, juga terhadap nukleofilik membran sel yang akan menyebabkan meningkatnya produksi senyawa reactive oxygenspecies (ROS) dalamtubuh. Keadaan tersebut dapat menyebabkan terjadinya stres oksidatif. Stres oksidatif dapat menyebabkan kerusakan seluler dan karsinogenesis. ${ }^{2,3,5,6,7}$

Hepar merupakan organ yang penting dalam mempertahankan homeostasis metabolisme tubuh diantaranya melalui detoksifikasi dan ekskresi limbah produk endogen dan xenobiotik polutan, termasuk formalin. Stress oksidatif yang ditimbulkan formalin dapat menyebabkan perubahan morfologi sel hepar., ${ }^{71}$

Kulit manggis atau Garcinia Mangostana Linn (GML) adalah salah satu tanaman tropis asli Indonesia yang berasal dari Kalimantan. Penelitian fitokimia dari tanaman ini telah mengungkap kandungan xanton yang telah menunjukkan berbagai bioaktifitas, antara lain antiinflamasi, antibakterial, antifungal, antitumor dan antioksidan. Xanton dari GML merupakan sumber antioksidan alamiah yang berfungsi menurunkan senyawa oksigen reaktif. Senyawa xanton yang telah teridentifikasi, diantaranya adalah 1,3,6-trihidroksi-7metoksi-2,8-bis(3- metil-2-butenil)- 9H-xanten-9-on and 1,3,6,7- tetrahidroksi-2,8-bis(3-metil-2-butenil)9Hxanten-9-on. Keduanya lebih dikenal dengan nama alfa mangostin dan gamma-mangostin. ${ }^{10,11,12,13}$

Penelitian terhadap aktivitas ekstrak GML menunjukkan adanya aktivitas antiradikal terhadap DPPH, sedangkan alfa dan gamma mangostin pada kulit buah manggis menggunakan metode ferric thiocyanate juga 
menunjukkan aktivitas antioksidan. ${ }^{14}$ Dengan pemeriksaan spirometry kulit manggis menunjukkan aktifitas scavenging gugus radikal hidroksil dan radikal superoksida. ${ }^{15}$ Dari hasilpenelitianIka (2012) menunjukkan bahwa ekstrak kulit manggis dosis 200mg/ $\mathrm{kgBB}$ dan 400mg/kg BB memberikan efek perbaikan pada ulkus lambung selama 1 minggu. ${ }^{16}$

Berdasarkan uraian di atas maka muncul permasalahan apakah kulit manggis yang memiliki aktifitas antioksidan tersebut mampu mengeliminasi oksidatif stress/ kerusakan oksidatif yang dihasilkan dari paparan formalin, melalui pengamatan pada histopatologi hepar hewan coba. Hewan coba yang digunakan adalah tikus wistar, sebab sering digunakan sebagai binatang percobaan dalam peneliti an untuk mengetahui efek suatu zat terhadap tubuh. Tujuan dari peenelitian ini adalah p engaruh ekstrak kulit manggis dalam memperbaiki kerusakan seluler dari jaringan hepar akibat paparan formalin. Adapun hipotesis penelitian ini adalah kulit manggis sebagai antioksidan dapat memperbaiki kerusakan seluler dari jaringan hepar akibat paparan formalin.

\section{METODE PENELITIAN}

Populasi penelitian adalah tikus Wistar jenis kelamin jantan yang diperoleh dari Universitas Gajahmada (UGM) Yogyakarta. Tehnik pengambilan sampel dilakukan secara acaksederhana (simple random sampling). Sampel diambil dari tikus wistar yang sudah memenuhi kriteria inklusi dan eksklusi sehingga dianggap cukup homogen. Semuanya diambil secara acak dari tikusyang sudah diadaptasi pakan selama1 minggu.

Kelompok kontrol negatif diberi placebo/aquades saja tanpa pemberian formalin hingga masa terminasi. Sedangkan kelompok kontrol positif dan kelompok perlakuan diberi formalin selama 21 hari. Randomisasidilakukan setelah pemberian formalin selama 21 hari tersebut. Selanjutnya sampel dibagi menjadi 3 kelompok secara random. Kelompok kontrol postitif diberi placebo selama 1 minggu. Kelompok perlakuan 1 diberi EKM 200mg/ kgBB/ hari per sonde selama 1 minggu. Kelompok perlakuan 2 diberi EKM $400 \mathrm{mg} / \mathrm{kg} \mathrm{BB} /$ hari per sonde selama 1 minggu.
Kriteria inklusi sampel penelitian ditetapkan sebagai berikut: Berat badan : 150- 200 gram, Umur 12 minggu, tikus dalam keadaan sehat da aktif dan anatomi luar tampak normal. Kriteria eksklusi adalah tikus sakit dan terlihat tidak aktif sewaktu mendapat perlakuan.

Besar sampel setiap kelompok perlakuan minimal 5 ekor tiap kelompok, oleh karena terdapat 4 kelompok maka dibutuhkan 20 ekor tikus. Guna mengantisipasi dropout maka ditambah masing-masing kelompok 1 tikus.

Bahan yang diambil dalam penelitian ini berasal dari kulit buah manggis matang warna merah kecoklatan, yang sudah layak konsumsi. Kulit buah manggis dipisahkan dari buahnya ,dibersihkan dari kotorannya, untuk diproses selanjutnya .Bahan lain yang diperlukan yaitu etanol 96\%, akuades dan botol hasil ekstrak.

Bahan untuk Pembuatan Larutan Formalin adalah Larutan formalin (formaldehide 37\%) 50ml dan Aqua destilata 950ml. Bahan untuk metode baku histologi pemeriksaan jaringan adalah Larutan Bouin, Larutan bufer formalin 10\%, Parafin, Albumin, Hematoksilin Eosin, Asamacetat, Larutan Xylol, Alkohol bertingkat 30\%, 40\%, 50\%, 70\%, 80\%, 90\%, 96\% dan Aquades.

Alat penelitian yaitu Kandang tikus, Sonde lambung bahan besi dengan diameter $2 \mathrm{ml}$, panjang 7-8 $\mathrm{cm}$, Spuit 1cc (tuberkulin), Skalpel, PinsetChirugis, Guntinglurus, Botol untuk menyimpan organ.

Alat untuk yang dibutuhkan untuk pembuatan ekstrak kulit manggis yaitu Oven, timbangan, gelas Erlenmeyer, corong gelas, kertas saring, labu evaporator, labupenampungetanol, evaporator, pendingin spiral/ rotary evaporator, Water Pump, Water pump, Water bath, Vacum pump.Alat untuk pemeriksaan histopatologis jaringan hepar mikroskop cahaya olympus BX 41, object glassdandeck glass, dan kamera digital

Penelitian ini merupakan penelitian eksperimental laboratorik dengan rancangan penelitian menggunakan post testcontrol group design dengan binatang tikus wistar sebagai subyek percobaan. 
Gambar1. Skema rancangan penelitian

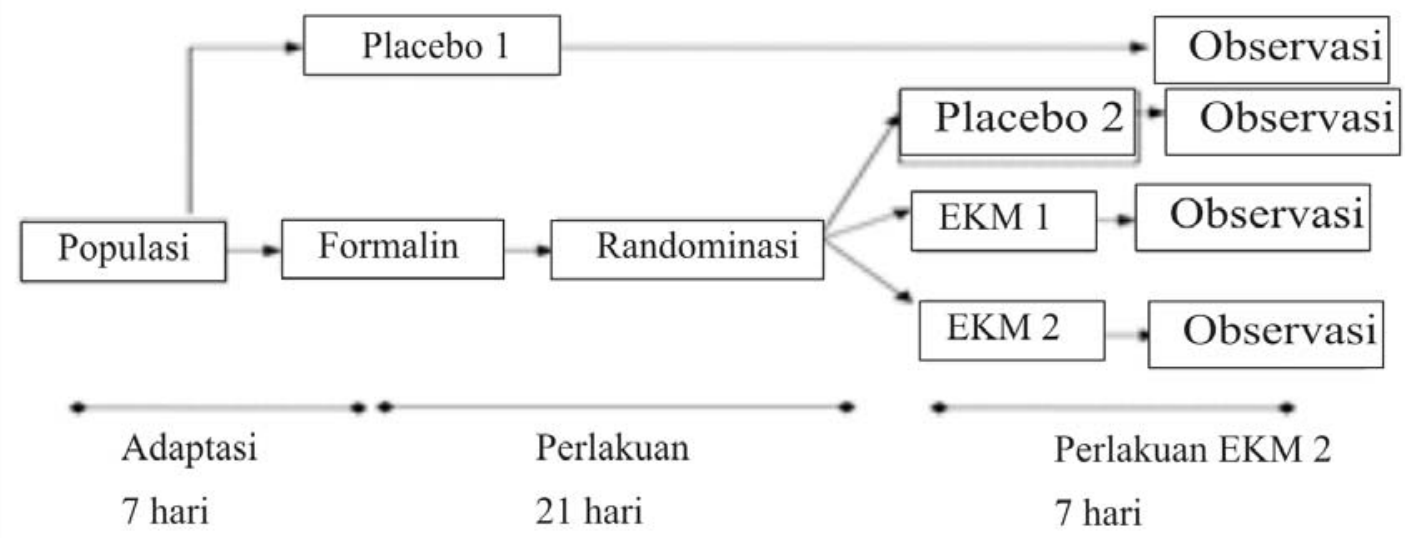

Keterangan :

Placebo 1 = pelarut dari formalin dan aekstrak kulit manggis, yaitu aquades 3mL.

Placebo 2 = pelarut dari ekstrak kulit manggis, yaitu aquades (steril water) $3 \mathrm{~mL}$.

Formalin $=$ Formalin 200mg/kgBB/hari per sonde

EKM 1 = Ekstrak kulit manggis dosis 200mg $/ \mathrm{kgBB} /$ hari personde

EKM $2=$ Ekstrak kulit manggis dosis $400 \mathrm{mg} / \mathrm{kgBB} / \mathrm{hari}$ per sonde

Data yang dikumpulkan merupakan data primer, yaitu gambaran histopatologi jaringan hepar tikus wistar jantan dari setiap kelompok. Hepar yang diambil dari tikus kemudian dibuat 1 preparat histopatologi pewarnaan Hemaktosilin Eosin. Preparat dilihat di bawah mikroskop cahaya dengan pembesaran $400 \mathrm{x}$ dalam 5 lapangan pandang. Setiap lapangan pandang dihitung 20 sel hepatosit dan dinilai kerusakannya tiap sel. Kemudain dihitung rerata bobot skor tingkat kerusakan hepatosit dari lima lapangan pandang. Tingkat keruskan sel hepar diamati dengan kriteria Manja Roenigk seperti tabel di bawah ini. Pengamatan preparat histopatologi telah dikonsulkan oleh pakar Patologi Anatomi.
Tabel 1. Skor penilaian tingkat kerusakan hepatosit kriteria Manja Roenigk. ${ }^{8}$

\begin{tabular}{|c|l|c|}
\hline No & Tingkat kerusakan & Skor \\
\hline 1 & Normal & 1 \\
2 & Degenerasi parenkimatosa & 2 \\
3 & Degenerasi hidropik & 3 \\
4 & Nekrosis & 4 \\
\hline
\end{tabular}

Sumber :Tamaddkk, 2011

Data yang diperoleh diolah dengan program komputer SPSS 18.0 for Windows. Data tersebut diuji 
normalitasnya dengan uji Saphiro Wilk. Jika didapatkan distribusi data yang normal, maka dilakukan uji beda menggunakan uji statistik parametrik One Way ANOVA, dan jika didapatkan perbedaan yang bermakna, maka dilanjutkan dengan uji statistik Post Hoc (Tukey HSD). Penelitian ini dilakukan setelah mendapatkan persetujuan etika penelitian yang diperoleh dari Komisi Etik Penelitian Kesehatan dan Kedokteran Universitas Diponegoro Semarang.

\section{HASIL DAN PEMBAHASAN}

Hasil pengamatan mikroskopis yang mewakili masingmasing kelompok (Gambar 1) tidak ada sampel yang mati dan dieksklusi selama penelitian, Akan tetapi terjadi perbedaan kerusakan struktur histopatologi hepar tikus wistar yang diperoleh dari pengamatan mikroskopik melalui lima lapangan pandang yang berbeda terhadap seluruh kelompok (Tabel 2).

Tabel 2. Hasil skor kerusakan gambaran histopatologi hepar

\begin{tabular}{|c|c|c|c|c|c|}
\hline No & Kel & Mean & $\begin{array}{c}\text { Nilai } \\
\text { Max }\end{array}$ & $\begin{array}{c}\text { Nilai } \\
\text { Min }\end{array}$ & P \\
\hline 1 & K (-) & $1,95 \pm 0,21$ & 2,17 & 1,72 & $\mathrm{p}=0,00$ \\
2 & $\mathrm{~K}(+)$ & $2,82 \pm 0,12$ & 2,95 & 2,69 & \\
3 & $\mathrm{P} 1$ & $2,69 \pm 0,06$ & 2,76 & 2,62 & \\
4 & $\mathrm{P} 2$ & $2,72 \pm 0,10$ & 2,63 & 2,41 & \\
\hline
\end{tabular}

Pada pemeriksaan laboraturium pengamatan mikroskopik kerusakan struktur histopatologi hepar tikus wistar, bahwa ada perbedaan yang bermakna secara statistik dari analisa One Way Anova didapatkan nilai $\mathrm{p}=0,000$ pada keempat kelompok.

Gambar 2: grafik kerusakan sel hepar

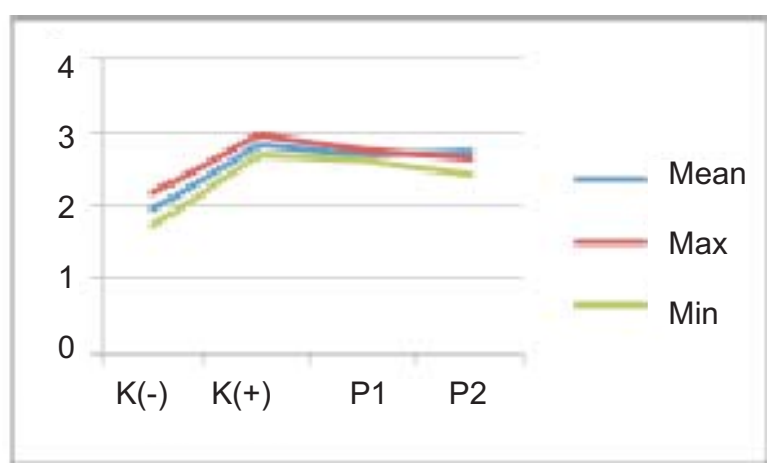

Adapun hasil perbedaan tiap-tiap kelompok setelah dilakukan analisa Post Hoc dijelaskan pada Tabel 3:

Tabel 3. Perbedaan skor kerusakan gambaran histopatologi hepar pada tiap-tiap kelompok

\begin{tabular}{|c|c|c|c|c|}
\hline & $\mathrm{K}(-)$ & $\mathrm{K}(+)$ & $\mathrm{P} 1$ & $\mathrm{P} 2$ \\
\hline $\mathrm{K}(-)$ & - & 0,000 & 0,000 & 0,000 \\
\hline $\mathrm{K}(+)$ & 0,000 & - & 0,715 & 0,008 \\
\hline $\mathrm{P} 1$ & 0,000 & 0,715 & - & 0,287 \\
\hline $\mathrm{P} 2$ & 0,000 & 0,008 & 0,287 & - \\
\hline
\end{tabular}

Terdapat berbedaan yang bermakna $(p=0,000)$ pada tingkat kerusakan strutkur histopatologi hepar antara kelompok kontrol negatif (K-) dengan ketiga kelompok yang lain. Hal ini menunjukkan bahwa pemberian formalin selama 21 hari cukup membuat kerusakan pada hepar. Terdapat perbedaan bermakna $(p=0,008)$ antara kelompok perlakuan 2 (P2) dengan kelompok kontrol positif $(\mathrm{K}+)$, sedangkan antara kelompok perlakuan 1 (P1) dengan kelompok kontrol positif $(\mathrm{K}+)$ tidak terdapat perbedaan yang bermakna $(0,718)$. Hal ini menunujukkan bahwa pada dosis $400 \mathrm{mg} / \mathrm{kg} \mathrm{BB} / \mathrm{hari}$ ekstrak kulit manggis menujukkan efek perbaikan seluler akibat jejas formalin, sedangkan pada dosis 200mg/ kgBB /hari belum menunjukkan efek perbaikan.

Gambar 3. Gambaran histopatologi pada keempat kelompok yaitu kelompok kontrol negatif (gambar A), kelompok kontrol positif (gambar B), kelompok perlakuan 1 (gambar C) dan kelompok perlakuan 2 (gambar D).

Pada kelompok kontrol negatif (K-) yaitu kelompok tikus tanpa pemberian formalin maupun ekstrak Kulit Manggis, nampak gambaran histopatologi hepar dalam keadaan normal. Hal ini dapat dilihat dari sel-sel hepatosit mempunyai inti sel yang masih baik.

Pada kelompok kontrol positif $(\mathrm{K}+)$ yaitu kelompok tikus dengan pemberian formalin 21 hari kemudian pemberian placebo 7 hari, tampak kerusakan jaringan yang cukup tinggi. Demikian pula pada kelompok perlakuan P1 dan P2, yaitu kelompok tikus dengan 


\section{Gambar A}

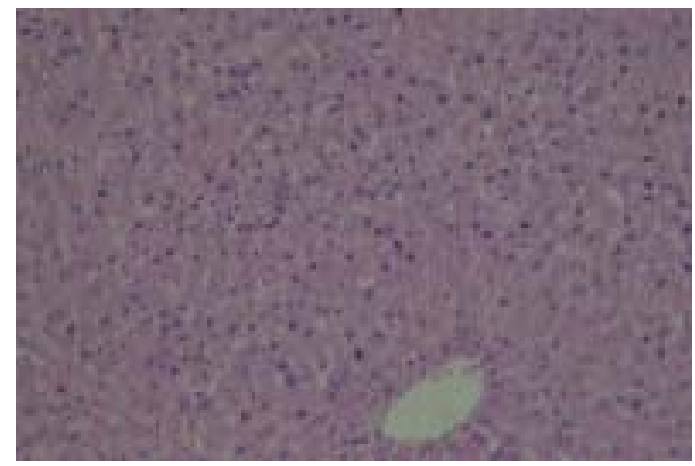

Gambar B

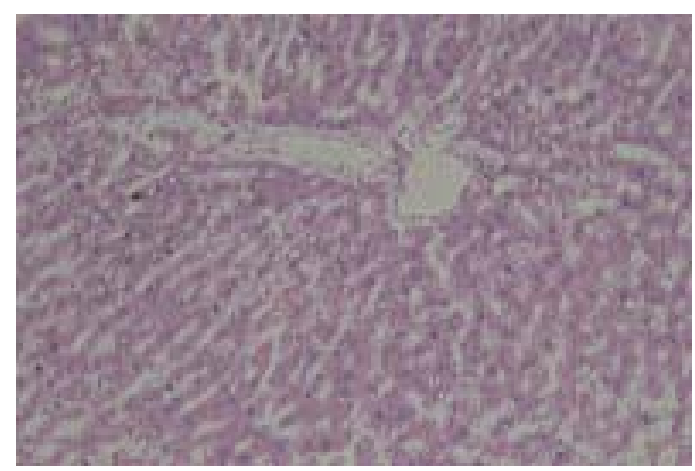

Gambar C

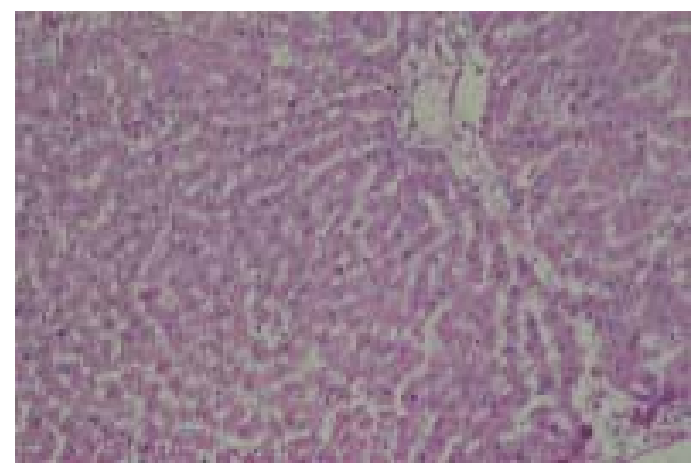

Gambar D



pemebrian formalin 21 hari kemudian pemberian ekstrak kulit manggis selama 7 hari, tampak kerusakan jaringan hepar yang masih cukup tinggi.

Pada pemeriksaan preparat histopatologi kelompok tersebut nampak gambaran jaringan hepar yang mengalami kerusakan dengan beberapa sel mengalami kematian nekrosis. Sel hepar yang mengalami kerusakan akibat jejas kimiawi formalin mengalami perubahan morfologi sel. Perubahan reversibel disebut sebagai degenerasi . Gambaran sel di bawah mikroskop cahaya meliputi tahapan pembengkakan sel dan perubahan berlemak. Pembengkakan sel merupakan manifestasi pertama pada hampir semua jejas sel, sebagai akibat pergeseran air ekstraseluler ke dalam sel. Perubahan tahapan ini disebut degenerasi parenkim. Bila kerusakan berlanjut ke tahap yang lebih berat maka sel mengalami perubahan berlemak, dimana tampak vakuol vakuol kecil pada sitoplasmanya, ini disebut degenerasi hidropik. Pada tahap lanjut akibat jejas yang progresif, sel akan melampaui point of no return ,memasuki tahap kematian sel di mana sifatnya irreversibel. Tahapan ini sel mengalami kematian yang disebut nekrosis. ${ }^{8,17,18,19}$

Formalin yang masuk ke dalam tubuh dimetabolisme dengan cepat di hepar.Asam format sebagai hasil metabolit formalin dapat bereaksi dengan sistem enzim tetrahidrofolat dan menimbulkan atom karbon yang bersifat elektrofilik. Hal ini merupakan Reactive Oxigent Species (ROS) yang mengakibatkan kerusakan oksidatif.

Terdapat berbedaan yang bermakna $(p=0,000)$ pada tingkat kerusakan gambaran histopatologi jaringan hepar antara kelompok kontrol negatif (K-) dengan ketiga kelompok yang lain. Perbandingan antara kelompok kontrol negatif (K-) dengan kelompok kontrol positif $(\mathrm{K}+)$ menunjukkan perbedaan yang bermakna $(\mathrm{p}=0,00)$. Perbandingan ini menunjukkan bahwa pemberian formalin selama 21 hari, cukup membuat kerusakan pada jaringan hepar. Meskipun pada kelompok $\mathrm{K}+$ tikus mempunyai masa 7 hari tanpa pemberian formalin (placebo) sehingga ada kemungkinan proses regenerasi pada sel hepar, namun waktu 7 hari ini belum cukup untuk kembali kepada morfologi sel yang normal.

Perbandingan antara kelompok K- dengan kelompok perlakuan baik P1 maupun P2 menunjukkan perbedaan 
yang bermakna $(p=0,00)$. Hal ini menunjukkan pemberian Ekstrak kulit manggis selama 7 hari, baik pada dosis $200 \mathrm{mg} / \mathrm{kg}$ BB (kelompok P1) maupun 400 mg/kgBB (kelompok P2), belum mengembalikan sel hepar pada morfologi yang normal.

Terdapat perbedaan bermakna antara kelompok perlakuan 2 (P2) dengan kelompok kontrol positif (K+) $(\mathrm{p}=0,008)$, sedangkan antara kelompok perlakuan1 (P1) dengan kelompok kontrol positif $(\mathrm{K}+)$ tidak terdapat perbedaan yang bermakna $(0,718)$. Hal ini menunujukkan bahwa pemberian ekstrak kulit manggis selama 7hari dosis $400 \mathrm{mg} / \mathrm{kg}$ BB/hari menujukkan efek perbaikan seluler akibat jejas formalin, sedangkan pada dosis 200mg/kg BB /hari belum menunjukkan efek perbaikan.

Dari hasil pengamatan mikroskopik tersebut menunjukkan bahwa ekstrak kulit manggis mampu memberikan efek perbaikan terhadap struktur histologi hepar yang terpapar formalin. Kulit manggis mempunyai aktivitas farmakologi, diantaranya efek antioksidan dan antiinflamasi. Xanton gammamangostin dan alfa mangostin yang terkandung dalam kulit manggis menunjukkan aktifitas scavenging radikal bebas. Penelitian Chomnawang (2007) menujukkan ekstrak kulit manggis secara signifikan menujukkan aktifitas antioksidan dengan metode DPPH, ekstrak kulit manggis mampu mereduksi ROS yaitu anion superoksid (O2-) dari sel PML (Polimorfonuclear Leucocytes). Di samping itu Xanton Gamma-mangostin juga mempunyai kemampuan antiinflamasi melalui penghambatan aktivitas siklooksigenasi (COX). ${ }^{20}$

Pada penelitian ini jejas kimiawi formalin pada jaringan hepar dapat tereduksi oleh efek antioksidan dan antiinflamasi kulit manggis. Hal ini terbukti pada perbandingan yang cukup signifikan antara kelompok kontrol positif $(\mathrm{K}+$ ) dengan kelompok (P2). Pemberian ekstrak kulit manggis 400mg/kg BB/hari selama 7 hari mampu memberikan efek perbaikan seluler jaringan hepar. Sementara itu perbandingan antara kelompok P2 dengan kelompok kontrol negatif (K-) menunjukkan perbandingan yang cukup signifikan, ini berarti pemberian ekstrak kulit manggis pada kelompok P2 belum mampu mengembalikan jaringan pada gambaran morfologi yang normal. Hal ini dimungkinkan pemberian ekstrak kulit manggis hanya selama 7 hari sehingga efek terapetik yang terjadi belum maksimal.

\section{KESIMPULAN}

1. Terdapat perbedaan yang signifikan $(p=0,008)$ gambaran histopatologi jaringan hepar pada kelompok tikus yang diberi ekstrak kulit manggis 400mg/kg BB/hari (P2) dengan kelompok kontrol positif $(\mathrm{K}+)$.

2. Tidak terdapat perbedaan yang signifikan $(\mathrm{p}=0,715)$ gambaran histopatologi jaringan hepar pada kelompok tikus yang diberi ekstrak kulit manggis 200mg/kgBB/hari (P1) dengan kelompok kontrol positif $(\mathrm{K}+)$.

3. Terdapat perbedaan yang signifikan $(0,00)$ gambaran histopatologi jaringan hepar kelompok kontrol negatif (K-) dengan ketiga kelompok yang diinduksi formalin, baik diberi ekstrak kulit manggis (P1 dan P2) maupun yang tidak $(\mathrm{K}+)$

\section{DAFTARPUSTAKA}

1. Harmita, 2006, Amankah Pengawet bagi Manusia, FMIPA-UI Depok, www.jurnalfarmasi.ui.ac.id

2. Jinxiang DLG, 2012, Of formaldehyde inhalation on renal tissue SOD and GSH levels, CAT and MDA, http://www.cn-articles.com/?i388373-Of-formaldehyde-inhalation-on-renal-tissue-SOD-and-GSH-levels-CAT-and-MDA

3. Mahdi C, Aulaniam, danWidodo. 2007. Yogurt Sebagai Detoksidan yang Efektif terhadap Toksisitas Formalin yang terpapar dalam Makanan. ejournal.umm.ac.id .15 (I):.

4. Rohmah I. N. 2012, Perbedaan Jumlah Nekrosis Sel Otak dan Nilai pH Darah Tikus Wistar pada Pemberian Formalin peroral Dosis Bertingkat, Program Magister Biomedik dan PPDS Ilmu Kedokteran Forensik, Universitas Diponegoro, Semarang

5. U.S. Department of Health and Human ServicesPublic Health Service National Toxicology Program(NTP).2010. Report on Carcinogens Background Document for Formaldehide, January 2010. www.ntp.niehs.nih.gov/ntp/roc/twelfth/2009/ 
formaldehyde_bd_final.pdf

6. UNEP publications, SIDS Initial Assesment . 2002 Report for Formaldehide.www.inchem.org/ documents/sids/sids/FORMALDEHYDE.pdf [cited: 2002 March]

7. U.S.Departement of Health and Human ServicesAgency For Toxic Substances and Disease Registry (ATSDR).2010. Toxicological profile for formaldehyde.Atlanta,USA;July1999.www.atsdr. cdc.gov/toxprofiles/tp111.pdf [cited: 2010 feb 12]

8. Tamad FSU, Hidayat ZS, danSulistyo H. 2011. Gambaran Histopatologi Tikus Putih setelah Pemberian Jinten Hitam Dosis 500mg/kg BB, 1000mg/kgBB dan 1500mg/kgBB selama 21 hari (subkronik), Jurnal Mandala of Health, 5 (III).

9. Jivai J, dan Y Nasni. 2008. Pengaruh Pemberian Tahu berformalin terhadap Gangguan Fungsi Hati dan terbentuknya Radikal Bebas dalam tubuh Tikus Putih. Jurnal Sains dan Teknologi Farmasi. 13 (I)

10. Nugroho A.E. 2012. Manggis: dari kulit Buah yang Terbuang hingga Menjadi Kandidat suatu Obat. Journal of Traditional Medicine . Fakultas Farmasi UGM- Ikatan Apoteker Indonesia (IAI) DIY. http:/ /mot.farmasi.ugm.ac.id/artikel-52 .

11. Pedraza, C. J, Rodriguez C. N, IbarraM, O, and Rojas,P.J.M. 2008. Medicine Properties of Mangosteen (Garcinia Mangostana). Food and Chemical Toxicology, 46 : 3227-3239.

12. Putra,S. R. 2012. Rahasia Keajaiban Kulit Buah Manggis. DIVA Press.

13. Shabella R. 2011. Terapi Kulit Manggis. Galmas Publisher.

14. Herman, F. T., 2009, Uji Aktivitas Penangkap Radikal DPPH (1,1-Difenil-2-Pikrilhidrazil) oleh Isolat Alfa Mangostin Kulit Buah Manggis (Garcinia mangostana L.), Fakultas Farmasi Universitas Muhammadiyah Surakarta, Surakarta

15. Kosem,N and Youn-Hee H. A. N. 2007, Antioksidan and cytoprotective antivities of methanolic extract from Garcinia mangostana Hull, microbiology department, Mahidol University, Bangkok.
Scienceasia 33: 283-92

16. Ika, K. 2012. Efek ekstrak etanolik kulit buah manggis pada healing model ulkus lambung tikus wistar yang dipapar indometasin, melalui efek anti-inflamasi dan angiogenesis, Universitas Brawijaya (disertasi)

17. Ramachandran R, and Kakar S. 2009. Histological patterns in Drug-Induced Liver Disease.Clin Pathol journal. 62 (III) :481-492.

18. Robins S L, Kumar V, danCotran RS. 2007. Bukuajarpatologi. Edisi 7 volume 1.Editor: AsroruddinM, HartantoH, Darmaniah N. Jakarta: EGC; 2007: p.3-31

19. Sudiono J, Kurniadhi B, Hendrawandan A, DjimantoroB. 2003. .Ilmu Patologi. Perubahan patologisel dan jaringan. Jakarta. EGC.

20. ZarenaAS,and Sankar KU. 2009. A Study of AntioxidantProperties from GarciniaMangostana L. Pericarp Extract. Acta Sci. Pol., Technol. India: Central Food Technological Research Institute. 8 (1) : 23-34. 